\title{
ANTIBACTERIAL EFFECT OF NANNOCHLOROPSIS OCULATA AS ROOT CANAL STERILIZATION MATERIAL ON STREPTOCOCCUS MUTANS BIOFILM
}

\author{
Diana Soesilo*, Sinta Puspita*, Phebe Fedora Christabe/**
}

${ }^{*}$ Department of Conservative Dentistry, Dentistry Faculty, Universitas Hang Tuah

** Student of Dentistry Faculty, Universitas Hang Tuah

Correspondence: diana.soesilo@hangtuah.ac.id

Keywords:

Streptococcus mutans

biofilm, Nannochloropsis

oculata, Antibacterial,

Calcium Hydroxide

\section{ABSTRACT}

Background: Streptococcus mutans in the most frequent microbiota that causes pulp necrosis because of caries. The microorganism that is colonized and embedded in the biofilm matrix is resistant to antimicrobials compared to planktonic cells. Root canal sterilization materials must have good biocompatibility with tissues. Nannochloropsis oculata is an algae that contains various compounds such as terpenoids, alkaloids, and flavonoids that have potential as antibacterial and antioxidant and can be used as alternative to root canal sterilization.

Method: This research was true experimental laboratory research with posttest only control group design. The antibacterial potential of Nannochloropsis oculata was tested using the biofilm method, divided into 5 groups. The control group was: $K$ - (aquadest), $K+$ (calcium hydroxide), and the treatment group was given Nannochloropsis oculata: P1 (0.625\%), P2 (1.25\%), and P3 (2.5\%). Congo Red method test was to determine the formation of biofilm that shows black strains on agar. While biofilm test with Microtiter Plate Assay to measure the value of biofilm that were inhibited in Optical Density $(O D)$ value in the ELISA Reader. The lower the value, the more biofilm inhibited, with OD value, inhibition percentage could counted

Result: The result of all treatment groups were increasing in percentage inhibition value shows inhibition in biofilm growth $(p<0.05)$.

Conclusion: Nannochloropsis oculata had an antibacterial effect on the biofilm of Streptococcus mutans

\section{BACKGROUND}

Pulp necrosis requires root canal treatment, which is dental treatment by removing the entire pulp tissue, both in the pulp chamber and root canal ${ }^{1}$. Root canal treatment can be divided into three stages, biomechanical preparation of root canals, disinfection and obturation.

The most frequent microbiota that causes pulp necrosis because of caries encountered is Streptococcus mutans (S. Mutans). This microorganism produces organic acids, especially lactic acid by fermenting carbohydrates on the surface of the teeth and make a decrease in salivary $\mathrm{pH}$ below 5.5 which will result demineralization of the tooth surface and dental caries will formed ${ }^{2}$. Biofilm are colonies of microorganisms that consist of cells from various kinds of bacteria that attach to one another on the surface of the teeth in irreversible form ${ }^{3}$. The formation of biofilm is a defense mechanism for bacteria to stay alive in environmental conditions in the oral cavity and is not easily attacked by the immune response of the host or drugs ${ }^{4}$. This formation process occurs through several phases, which are the formation of 
pellicles on the surface of the tooth, the beginning of attachment of bacteria, bacterial colonization, maturation, and release of biofilm cells ${ }^{5}$. The formation of biofilm can be influenced by several things such as $\mathrm{pH}$ levels, nutrients, and host defense ${ }^{6}$.

Calcium hydroxide is the first choice intracanal medicament and is commercially available as a paste or pure powder mixed with water or saline to make a paste of the desired consistency. The characteristics of calcium hydroxide are having a high $\mathrm{pH}$ (12) by working synergistically with sodium hypochlorite to degrade pulp tissue, broad-spectrum antimicrobial agents, prolonged anti-microbial effect to control the serous exudate. Disadvantages of calcium hydroxide is it can weaken dentin if left in the root canal for a long period of time ${ }^{7}$. The highest antimicrobial effect of calcium hydroxide and the lowest toxicity is at a concentration of $60 \%{ }^{8}$. One of the requirements for materials used in dentistry should be non-toxic, not irritating and must have biocompatibility properties or the material produced must not have a detrimental effect on the biological environment both locally and systemically. Ideally, a root canal sterilization material must have good biocompatibility with the tissue. This biocompatibility includes the degree of cytotoxicity, mutagenicity, and carcinogenicity in addition to having antimicrobial properties ${ }^{9}$.

Algae is rich in fatty acid-derived compounds, oxylipin, which functions as an antibacterial for pathogenic bacteria ${ }^{10}$. Oxylipin is a secondary metabolite product that has antibacterial properties, besides that, marine algae are also rich in flavonoid compounds which have antimicrobial benefits by damaging bacterial cell walls ${ }^{11,12}$. Nannochloropsis oculata microalgae is an algae that contains various compounds such as terpenoids, alkaloids, and flavonoids that have potential as antibacterial and antioxidant ${ }^{13}$. Previous studies conducted by Revianti and Parisinni, showed that the extract of Nannochloropsis oculata had a toxicity effect at concentrations above $2.5 \%$ and did not show a toxicity effect at concentrations below $2.5 \%{ }^{14}$.

Based on this data, the researcher wants to develop a research on the antibacterial power of green microalgae Nannochloropsis oculata on the biofilm of the bacterium Streptococcus mutans which is included in the bacteria that causes dental caries disease which can cause pulp death.

\section{MATERIAL AND METHOD}

This research was conducted based on approval from the Research Ethics Commission of the Faculty of Dentistry, Hang Tuah University with number EC/006/KEPK-FKGUHT/VII/2019. This type of research was a true experimental laboratory research. The groups were divided into 5 , which were the negative control group ( $S$. mutans $0.1 \mathrm{~mL}$ $+0.1 \mathrm{~mL}$ distilled water (K-), the first positive control group ( $S$. mutans $0.1 \mathrm{~mL}+60 \%$ calcium hydroxide $(\mathrm{K}+)$, the treatment group that was given Nannochloropsis oculata with a concentration of $0.625 \% 0.1 \mathrm{~mL}(\mathrm{P} 1)$, the treatment group given Nannochloropsis oculata with a concentration of $1.25 \% 0.1 \mathrm{~mL}$ (P2), and the treatment group given Nannochloropsis oculata with a concentration of $2.5 \% 0.1 \mathrm{~mL}$ (P3).

The materials used in this research were suspension of Streptococcus mutans, BHIB, Congo red agar, green microalgae Nannochloropsis oculata with concentrations of $0.625 \%, 1.25 \%$, and $2.5 \%$, calcium hydroxide $60 \%$, crystal violet $0.1 \%$, Tween 80 concentration of $2 \%$, and sterile distilled water.

Streptococcus mutans bacteria were cultured in liquid BHI media which had been 
incubated for $2 \times 24$ hours in an anaerobic atmosphere. Then making suspension of Streptococcus mutans bacteria in the BHIB turbidity was synchronized with the $0.5 \mathrm{Mc}$ Farland standard.

The process of making green microalgae Nannochloropsis oculata for a concentration of $2.5 \%$ was obtained by weighing the microalgae powder of Nannochloropsis oculata as much as 0.5 $\mathrm{mg}$ and then dissolving it in $20 \mathrm{~mL}$ of distilled water. A $1.25 \%$ concentration was obtained from $0.25 \mathrm{mg}$ of Nannochloropsis oculata powder dissolved in 20 $\mathrm{mL}$ of distilled water. The concentration of $0.625 \%$ Nannochloropsis oculata was obtained from 0.125 $\mathrm{mg}$ of Nannochloropsis oculata powder dissolved in $20 \mathrm{~mL}$ of distilled water.

A qualitative test to detect biofilm formation was carried out using the Congo red agar method. Streptococcus mutans bacteria were rubbed on Congo red agar and incubated for 48 hours at $37^{\circ} \mathrm{C}$ in an anaerobic atmosphere. Check the plate after 48 hours, if a black colony is formed then it showed a strain of bacteria that produces biofilm. However, if the colony was red, the strain does not produce biofilm.

Quantitative test for biofilm formation using the microtiter plate assay method. Suspension of Streptococcus mutans which was equalized with $0.5 \mathrm{Mc}$ Farland solution was diluted to 1: $1000.1 \mathrm{~mL}$ of Streptococcus mutans culture and then put into 96-well rounded bottom plastic tissue culture plates (microtiter plates) and incubated overnight at $37^{\circ} \mathrm{C}$. Green microalgae Nannochloropsis oculata with concentrations of $0.625 \%, 1.25 \%$, and $2.5 \%$ were applied to each 96-well round-bottomed plastic tissue culture plate (microtiter plate) then incubated overnight at $37^{\circ} \mathrm{C}$. The contents of each 96 -well round-bottomed plastic tissue culture plate (microtiter plate) were removed and washed 3 times with $0.2 \mathrm{~mL}$ phosphate-buffered saline using a micropipette. Biofilm microorganisms attached to the 96-well round-bottomed plastic tissue culture plate (microtiter plate) were painted with crystal violet and rinsed using distilled water and then dried. Quantitative analysis of biofilm formation was done by adding Tween $80,2 \%$ concentration in every 96-well round-bottomed plastic tissue culture plate (microtiter plate). Optical density (OD) measurements were carried out using ELISA Reader with a wavelength of $570 \mathrm{~nm}$. Low OD values indicate the presence of antibacterial power at each concentration of green microalgae Nannochloropsis oculata.

The percentage of inhibition was the inhibition of Nannochloropsis oculata to the growth of Streptococcus mutans bacteria calculated by the formula:

$\%$ Inhibition = 1-(OD K(-) - OD P) / OD K (-) x 100\%

\section{RESULT}

The research data were analyzed descriptively to obtain an overview of the distribution and summation of data in order to clarify the presentation of results. Table 1 showed the average percentage value of Streptococcus mutans biofilm inhibition.

\begin{tabular}{|lll|}
\hline & Mean & SD \\
\hline K (-) & .1233 & .00519 \\
\hline K (+) & .2548 & .01976 \\
\hline P1 & .2899 & .05793 \\
\hline P2 & .2821 & .04188 \\
\hline P3 & .2708 & .02774 \\
\hline
\end{tabular}

Table 1. The mean value of Streptococcus $D E$ 


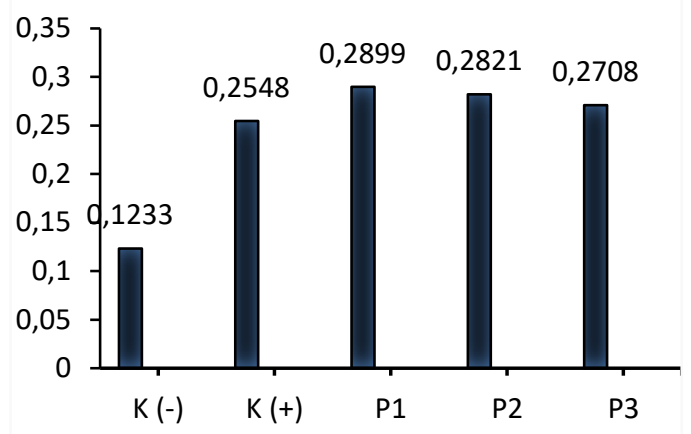

Graphic 1. Graphic average percentage of

Streptococcus mutans biofilm inhibition

Information: $\mathrm{K}(-) \quad$ (Aquadest); $\mathrm{K}(+) \quad$ (Kalsium Hidroksida 60\%); P1 (Nannochloropsis oculata 0.625\%); P2 (Nannochloropsis oculata 1.25\%); P3 (Nannochloropsis oculata 2.5\%).

Based on the average graph of the percentage of inhibition of Streptococcus mutans biofilm, the lowest percentage of aquades inhibition, and in the treatment group, the average percentage of inhibition in Nannochloropsis oculata was $0.625 \%$ (P1) highest compared to the other treatment groups. The presence of antibacterial power against the formation of Streptococcus mutans bacterial biofilm was characterized by an increase in the percentage inhibition value.

From the LSD test result, it was known that there were significant differences in the percentage value of biofilm inhibition in the negative control group to the positive control group and the treatment groups $\mathrm{P} 1, \mathrm{P} 2$ and $\mathrm{P} 3$. This was evidenced by the significance value of each group, which is $p<0.05$. There was no significant difference in the percentage value of biofilm in the group $\mathrm{K}(+)$ against P1, P2, P3 ( $p>0.05)$.

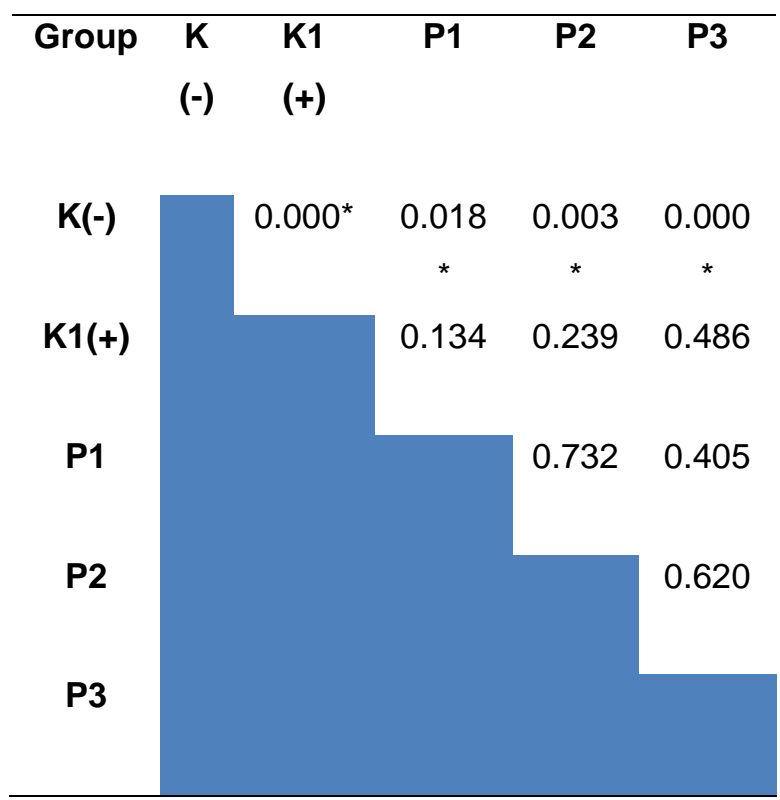

Table 2. LSD Test Result

Information: ${ }^{*} p<0,05$

\section{DISCUSSION}

Streptococcus mutans is a gram-positive cariogenic bacterium, facultative anaerobic ${ }^{15}$, nonmotile, round in shape, arranged like a chain and does not form spores, grows optimally at temperatures around $18{ }^{\circ} \mathrm{C}-40{ }^{\circ} \mathrm{C}$ diameter 0.7 - 09 $\mu \mathrm{m}^{16}$. In this research, bacterial Streptococcus mutans biofilm was checked quantitatively method with Congo red agar. The results showed that the black colonies that proved the strains of Streptococcus mutans had the ability to form biofilm.

This research used biofilm method because biofilm had a more complex structure than bacterial colonies that do not form biofilm. Biofilm was a collection of bacteria that attaches to a surface and is embedded in the polysaccharide extracellular matrix to protect bacteria from external influences so that they were not easily detached ${ }^{17}$. Extracellular Polymeric Substance (EPS) also caused antimicrobial resistance from biofilm by 
inhibiting the transport of antibiotics through biofilm ${ }^{18}$. This formation process occured through several phases, which were the formation of pellicles, the beginning of bacterial attachment, bacterial colonization, maturation, and release of biofilm cells 5 .

Nannochloropsis oculata was one of the green microalgae that had potential as an antibacterial and antioxidant ${ }^{13}$. Nannochloropsis oculata contains secondary metabolites which were active components that act as antibacterial. The secondary metabolite produced was generally used as an antibacterial ${ }^{19}$. Secondary metabolites in green microalgae Nannochloropsis oculata which were contained alkaloids, terpenoids, and flavonoids ${ }^{20}$.

This research used Nannochloropsis oculata in whole form so that all antibacterial components are still present in the powder used. Nannochloropsis oculata powder had been tested quantitatively on alkaloid and flavonoid components performed by the $\mathrm{AICl} 3$ Spectrophotometry method $(\lambda=415 \mathrm{~nm})$ for determination of flavonoid levels and colorimetric methods, Bromocresol Green reagents $(\lambda=430 \mathrm{~nm})$ for determination of alkaloid levels. The results obtained were $0.30 \% \mathrm{w} / \mathrm{w}$ flavonoids and $0.05 \% \mathrm{w} / \mathrm{w}$ alkaloids.

There were limitations in this research, Nannochloropsis oculata which was used was still in whole form. The antibacterial component in Nannochloropsis oculata was still mixed so that it cannot be ascertained that the specific antibacterial component plays a role in inhibiting the formation of biofilm. Although quantitative tests had been carried out, but only on the flavonoid and alkaloid components. There were other antibacterial components in Nannochloropsis oculata which played a role in inhibiting the formation of biofilm, but in this research quantitative testing could not be done. This research used Nannochloropsis oculata powder whose particles were still coarse, it was estimated that this affected the material in penetrating bacterial cell walls which caused the process of inhibiting the growth of Streptococcus mutans bacteria that had not worked optimally. That provided an opportunity for materials to be explored further.

This research was conducted to see the antibacterial power of Nannochloropsis oculata solution to the bacterial biofilm of Streptococcus mutans. The antibacterial power of Nannochloropsis oculata microalgae in inhibiting biofilm was seen from the difference in the average percentage of inhibition. The results showed that the positive control group with calcium hydroxide $60 \%$ had antibacterial power that had a significant effect, whereas in the treatment group P1 (concentration $0.625 \%$ ) had the most influential antibacterial power compared to the treatment group with a concentration of $1.25 \%$ or $2.5 \%$.

In all treatment groups (Nannochloropsis oculata solution) $0.625 \%$ (P1), $1.25 \%$ (P2) and $2.5 \%$ (P3) there were increases in the percentage value of inhibition of the concentration of Nannochloropsis oculata solution which showed increases in antibacterial power in inhibiting the formation of Streptococcus mutans biofilm. Nannochloropsis oculata $0.625 \%$ (P1) solution group had the highest percentage of inhibition compared to other concentrations which meant that Nannochloropsis oculata with a concentration of $0.625 \%$ had been effective to inhibit the formation of bacterial biofilm. Based on previous research conducted by Revianti and Parisihni, it was shown that the extract of Nannochloropsis oculata was not toxic to fibroblast stem cells with concentrations below $2.5 \%$ and showed toxicity effects at concentrations above $2.5 \%{ }^{14}$. 
In the negative control group (distilled water) the lowest percentage of inhibition was obtained compared to the positive control group and the treatment group. This showed that there is no inhibited Streptococcus mutans biofilm. Distilled water did not contain antibacterial compounds so it did not affect the growth of Streptococcus mutans.

The positive control group with calcium hydroxide had a more influential result in significantly inhibiting the formation of Streptococcus mutans biofilm. Calcium hydroxide is a material with a strong base with a $\mathrm{pH}$ of 12-13. Calcium hydroxide is the most common medicinal ingredient used today. This material was used as a medicinal material during endodontic therapy visits and has very good antibacterial properties. The antibacterial properties of calcium hydroxide are caused by the decomposition of $\mathrm{Ca}^{2+}$ and $\mathrm{OH}^{-}$ions. The lethal effect of hydroxyl ions was that it can damage bacterial cytoplasmic membranes, denaturated proteins and damage bacterial DNA ${ }^{21}$.

Calcium hydroxide and $2.5 \%$ Nannochloropsis oculata solution had an influential antibacterial power and could equally inhibit the formation of biofilm, but the results of research have Nannochloropsis oculata a higher percentage of inhibition. The content of alkaloids and flavonoids in Nannochloropsis oculata could inhibit DNA and cell walls in bacteria ${ }^{22}$.

The negative control group (Aquadest) showed a significant difference with the positive control of calcium hydroxide and the treatment group of Nannochloropsis oculata solution $0.625 \%$ (P1), 1.25\% (P2), and 2.5\% (P3). In the positive control group calcium hydroxide and the treatment of Nannochloropsis oculata solution $0.625 \%$ (P1) did not show any difference in the value of OD biofilm with the treatment group solution of Nannochloropsis oculata $1.25 \% \quad$ (P2) and Nannochloropsis oculata 2.5\% (P3), as evidenced by the value of $O D$ biofilm with the treatment group solution of Nannochloropsis oculata 1.25\% (P2) and Nannochloropsis oculata 2.5\% (P3). group significance was $p>0.05$.

The difference in the concentration of Nannochloropsis oculata's solution affected the amount of antibacterial content in the solution. In the solution of Nannochloropsis oculata the concentration of $0.625 \%$ (P1) and $1.25 \%$ (P2) might have almost the same antibacterial content so that it did not show significant differences to inhibit the formation of Streptococcus mutans biofilm. This showed that both had the same effectiveness in inhibiting the bacterium Streptococcus mutans biofilm.

\section{CONCLUSION}

Nannochloropsis oculata had an antibacterial power against the biofilm of the bacterium Streptococcus mutans with an effective concentration of $0.625 \%$ which had almost the same antibacterial power as calcium hydroxide.

\section{CONFLICT OF INTEREST}

There is no conflict of interest between authors

\section{ACKNOWLEDGEMENT}

The author would like to give this acknowledgement to Hang Tuah University Surabaya which has funded this research

\section{REFERENCES}

1. Grossman L I, Oliet S, Rio CED. 2014. Endodontics in Practice, Walters Kluwer Health Publishers. New Delhi

2. Adhani R, Sukmana B.I, Suhartono E. 2015. Effect $\mathrm{pH}$ on Deminerslization Dental Erosion. International Journal of Chemical Engineering and Applications. vol 6, no. 2. h. 138-141

3. Purbowati, R. 2018. Hubungan Biofilm dengan Infeksi : Implikasi pada Kesehatan Masyarakat dan Strategi Mengontrolnya. Jurnal IImiah Kedokteran, 5(1) : 1-14 
4. Peng X, Ekanayaka SA, McClellan SA, Barrett RP, Vistien K, Hazlett LD, 2017. Characterization of Three Ocular Clinical isolates of $P$. aeruginosa: Viability, Biofilm Formation, Adherence, Infectivity, and Effects of Glycyrrhizin. MDPI Journal Patogens 6(4): $1-17$

5. Vasudevan R, 2017. Dental Plaques: Microbial Community of the Oral Cavity. Journal of Microbiology \& Experimentation 4(1): 1-9

6. Oilo M, Bakken V, 2015. Biofilm and Dental Materials. MDPI Materials 8: 2887-2900

7. Garg, N and Garg, A. 2013. Textbook of Endodontics. $3^{\text {rd }}$ ed. Jaypee Brothers Medical Publishers. New Delhi. P. 210-230

8. Febrianita, E, Hadriyanto, W, Kristanti Y. 2016. Perbedaan Daya Anti Bakteri Siler Saluran Akar Berbahan Dasar Seng Oksid Eugenol, Resin Epoksi dan Mineral Trioxide Aggregate Terhadap Enterococcus faecalis. J. Ked Gi, vol 7. no. 2, April 2016. h. 41-47

9. Shanon Patel \& Justin J. Barnes 2016. Prinsip Endodontik. Edisi Kedua. EGC, hal. 51-94

10. Perez MJ, Falque E, Dominguez H, 2016. Antimicrobial Action of Compounds from Marine Seaweed. MDPI Marine Drugs 14(3): 1-38

11. Putri IA, Parisinni K, Wedarti YR, 2013. The Inhibition Effect Of Nannocloropsis oculata Extract Toward The Mixed Periodontopathogen Bacteria.

12. Saifudin A, Raharjo S, Eso A, 2015. Uji Aktivitas Antibakteri Ekstrak Metanol Rumput Laut (Kappaphycus alvarezii) pada Berbagai Tingkat Konsentrasi terhadap Pertumbuhan Bakteri Streptococcus mutans. Medula 3(1): 185-191

13. Agustini NWS, Afriastini M, Maulida Y, 2014. Potensi Asam Lemak Dari Mikroalga Nannochloropsis sp Sebagai Antioksidan dan Antibakteri. Seminar Nasional Seminar Nasional XI Pendidikan Biologi FKIP UNS.

14. Revianti S, Parisihni K, 2013. In Vitro Cytotoxicty Investigation of Nannochloropsis oculata Extractto Human Gingival Fibroblast Stem Cells. Surabaya: Programe Book and Abstracts at International Seminar Dental Expo $2^{\text {nd }}$ Dentisphere Faculty of Dentistry Hang Tuah University

15. Handini, AD. 2013. Perbedaan Topikal Aplikasi Bahan Casein Phospopeptide-Amorphous Calcium Phospate (CPP-ACP) dan Bahan Sodium Fluoride Terhadap Jumlah Koloni Streptococcus mutans pada Saliva Anak Usia 6-12 Tahun. Skripsi Fakultas Kedokteran Gigi Universitas Hasanuddin. H. 15-16

16. Samaranayake, 2011. Essential Microbiology for Dentistry. $4^{\text {th }}$ Ed. Addison Churchil Livingstone, p 275-283.
17. Nield-Gehrig\&Willman. 2011. Foundations of Periodontics for the Dental Hygienist. $3^{\text {rd }}$ Ed. Lippincott Williams and Wilkins Hal. 68-69; 8788; 97; 101-122

18. Homenta H, 2016. Infeksi Biofilm Bakterial. Jurnal e-Biomedik (eBm), 4(1): 1-11

19. Yanuhar U, 2016. Mikroalga laut Nannochloropsis oculata. Malang: UB Press pp 6-7

20. Sani RN, Nisa FC, Andriani RD, Maligan JM, 2014. Analisis Rendemen dan Skrining Fitokimia Ekstrak Etanol Mikroalga Laut Tetraselmis chuii. Jurnal Pangan dan Agroindustri 2(2): 121-126.

21. Mohammadi Z, Shalavi S, and Yazdizadeh, M. 2012. Antimicrobial Activity of Calcium Hydroxide in Endodontics : A Review. Chonnam Medical Journal, 48. 133-140.

22. Kartika GRA, Andayani S, Soelistyowati, 2016. Potensi Ekstrak Daun Binahong (Anredera cordifolia) Sebagai Penghambat Bakteri Vibrio harveyi. Journal of Marine and Aquatic Sciences, 2(2): 49-53. 